International Journal of Social Science and Economic Research

ISSN: $2455-8834$

Volume:06, Issue:05 "May 2021"

\title{
THE POLITICAL ECONOMY CONCEPT OF FOOTBALL INCHIANG MAI PROVINCE
}

\author{
Faize Anuntakan ${ }^{1}$, Asst. Prof. Dr. Pedithep Youyuenyong ${ }^{2}$ and Asst. Prof. Dr. Prasit Leepreecha ${ }^{3}$ \\ ${ }^{1}$ Master's degree student Political Economy, Faculty of Social Sciences Chiang Mai University \\ ${ }^{2}$ Faculty of Law, Chiang Mai University \\ ${ }^{3}$ Faculty of Social Sciences, Chiang Mai University
}

DOI: 10.46609/IJSSER.2021.v06i05.015 URL: https://doi.org/10.46609/IJSSER.2021.v06i05.015

\begin{abstract}
Academic article "The Political Economy Concept of Football in Chiang Mai Province", part of a master's thesis program in political economics, department of social sciences and development, faculty of social sciences, Chiang Mai University. Which the objective is to study the holistic problems of professional football clubs in Chiang Mai, classifying holistic problems as specific problems, by studying the developments which will lead to the power relations and industrial business of football clubs in Chiang Mai, and study various dimensions related to football clubs in Chiang Mai. This includes economic, social, political, cultural, and policy policies that support and direct professional football clubs in Chiang Mai, by looking through the political economics dimension. This, the authors presented through the concept of political economics, is explained on the foundations of the Marxism of "Karl Mark" and "Friedrich Engels", both of which see class divisions as the driving force of history. By which, Marx uses a method called dialectical materialism, which is the relationship between the upper and lower structures, Marx emphasizes the use of the economy as a determining factor in describing the upper structure as a matter of politics, law, and social consciousness. The findings will inform the condition and problems holistically to solve problems and develop football clubs in Chiang Mai, and to inform developments which will lead to the empowering relationship of the football club industry business in Chiang Mai, it also informs the various dimensions associated with football clubs in Chiang Mai, economic, social, political, and cultural aspects.
\end{abstract}

Keywords: Political Economy Concept / Professional Football / Professional Soccer Club

\section{Introduction}

Football in Thailand was first played during the reign of King Rama IV, but it is not a very popular sport in Thailand. Until the reign of King Rama V, football became increasingly popular, 


\section{International Journal of Social Science and Economic Research}

Volume:06, Issue:05 "May 2021"

because of the value of football. This supports football and makes it popular for foreigners in Thailand to play in the missionary YMCA club sport. During that time, there were competitions and training sessions with Thais, while foreigners who were skilled in football offered to help guide Thais, and football matches began frequently, making fun of the people who played and watched the tournament, until it became a popular sport later (Fong Kiedkaew, 1977). Later on, it was evident that football became very popular, giving the Department of Education a role in the development of student football, and responsible for managing and running sporting events in those days (Udthon Pidphayan, 1974). In the reign of King Rama VI, the Football Association of Siam was established and the administrative regulations of the Siam Football Council were printed, and the Siam Football League regulations were published, and the Siam Football Cup regulations were published, and the football clubs of many different agencies were established, the trophy was the first football match in Thailand (Thanomwong Krispetch, 1995). Later, the Football Association of Siam held a competition and a decision. As well as improving the rules of competition more internationally, and English football tournaments have been held, club-level competitions are being held to win royal trophies of A,B,C and D, other tournaments such as youth football, higher education football, and the king's cup are also held, etc. Including subsequently more football events, organized during the first university institution, with two major institutions in Thailand, that is Chulalongkorn University and Thammasat University are supporting football more widely among students, it is an example for universities to have the intention of arranging sporting events between domestic universities. Finally, the University of Thailand's sporting events were held, becoming one of the national sporting events (Thanomwong Krispetch, 1995). In addition to the events, the football association of Thailand and the sports authority of Thailand together with the provinces combined to organize football matches between the regions and districts, this gives people in other provinces the opportunity to compete and be able to develop sports, to become national team representatives later, as well as to open up opportunities for youth sports in Thailand. However, Thailand's football has not achieved much international success, making the football association of Thailand intend to develop football to be equal to other countries, in an endearing campaign to start pushing more football in Thailand towards professional sports. Professional football here means creating more jobs or building careers, or is it making a career playing football, if anyoneplays professional football, it will bring football to a higher standard, and if anyone plays a career, there can be motivations in terms of dedication, and rewards as training incentives. Nowadays, if anyone wants to become a professional football player, they may start out as a yaw player or a sculptor of a school famous for football, or start with the academy system of each famous club, as well as sports personnel from academies in sports. For example, the institute of physical education and practice is so hard that it is possible to eventually develop itself into a professional footballer (Pinyapan Pojjanalawan, 2007). There are 


\section{International Journal of Social Science and Economic Research}

ISSN: $2455-8834$

Volume:06, Issue:05 "May 2021"

many important factors that make football players want to develop themselves into professional footballers, including the income of professional footballers in major league clubs, as well as having a personal sponsor, and another important factor is the national service as a national footballer that many professional footballers want to get there as well.

Nowadays, before anyone can enter professional football, it is evident that football in Thailand has been experiencing problems for a long time, whether it is social problems such as violence in football, players themselves or fan issues, especially assaults between fans, or damage to public property, etc. The causes of these problems are caused by a number of factors, including the incitement of fans or intoxicated spectators, and mainly due to the cheerleading of each team that is provocative, causing these violence problems. The next problem is the lack of development of football players into professional sports from the public and private sectors, where the public and private sectors lack the promotion and support of continuous and systematic play, without seriously developing the skills of athletes, including a system of systematically organized domestic football competitions and not benefiting the development of football standards for Thailand. As well as club football management organizations, they are managed under a number of restrictions including personnel, budgets, and sponsorships, and the government has made these issues an obstacle to promoting and developing football for excellence and professional football.

The first official cause of professional football is that Thai Premier League companies have developed professional football from "Thailand Provillian Thai League", in 2005 or more asa Thai Premier League football player (Wikipedia, the free encyclopedia, Online 2021). Thai Premier League football has a registered capital of THB 5,000,000, and if any club participates in a competition under the Thai Premier League football, it is necessary to register as a legal entity or company, there must be wages for athletes, players are traded, and gate passes are traded to watch the game. It is also possible to trade foreign players, trade foreign players or bring in foreign players, as another factor in raising Thai football to be more or less equivalent to the foreign players league, because having foreign players to make Thai football more aggressive and attractive, in order to be a sedition and create a trend for Thais to cheer on their clubs (Wikipedia, free encyclopedia, Online 2021). The emergence of The Thai Premier League has led to the expansion of professional football in all provinces of Thailand, and local capitalists are became increasingly interested in the football flow, hopingto generate popularity both economic and socially, so capitalists have thrown huge sums of money into buying football teams in order to have the right and authority to manage the club. It will be found that most of the capitalists who invest in local professional football clubs have both private equity and politician capitalists behind them, because if they want to drive professional football in Thailand it requires a lot of money and power to drive, and also to hopefully voice the support of football 


\section{International Journal of Social Science and Economic Research}

ISSN: $2455-8834$

Volume:06, Issue:05 "May 2021"

for the major politicians in the province (Tawee Piyaosotsan, 2017). It is undeniable that football is irrelevant to politics, because we can now say that football clubs are used as political machines, an area where politicians communicate with the public instead of the political arena, and until the end those politicians gained a foothold from the club fans they do in returning to politics today (Daily Resolutions, 2019).

Nowadays professional football in Thailand is a type of business, both at the national and club levels, especially at club level, where profits and losses must be thought about, to earn enough money at the expense of the team. These duties are the duties of the club's management, if the national football team is the duty of the football association of Thailand to be the custodian, without focusing on profits or losses but focusing mainly on performance. Originally, at the national level, the benefits were relatively minimal, as all sports equipment was produced and used mainly in Thailand. However, nowadays, the business has become a product for Thai national athletes to bid against, whichever company bids higher will be the manufacturer of shirts for the Thai national team, or even the shirts in rehearsals will have sponsors who have to bid on the logo on the chest of the shirt, with the football association of Thailand having the authority to decide and consider only, as a matter of interest in professional football in Thailand. As well as the royalties for broadcasting football games to the football association, how much money is not known to sponsors that the country football association has never seen? Whether or not these funds will be developed for the Thai national team, everything will only be the power of the president of the football association of Thailand, but nevertheless, earning a lot of money from royalties or sponsors is not to see the development of football in the country. Nowadays, professional football in developed countries is evolving, for example hiring relatively high-end coaches to control training for Thai national team players, and including injectable funds that give players more motivation and appetite to win. It is evident that no matter how many eras have passed in football in Thailand, the benefits will improve the professional football industry in Thailand, or those benefits will derail professional football in Thailand.

In the research on "Political Economics on Football in Thailand", the objective is to study the holistic problems of professional football clubs in Chiang Mai, classifying holistic problems as specific problems, studying developments that will lead to power relations and industrial business of football clubs in Chiang Mai, and studying various dimensions related to football clubs in Chiang Mai. This includes economic, social, political, cultural, and policy policies that support and direct professional football clubs in Chiang Mai, in looking through the political economics dimension, which the authors explain through the concept of political economics, as follows: 
International Journal of Social Science and Economic Research

ISSN: $2455-8834$

Volume:06, Issue:05 "May 2021"

\section{Political Economics Concepts}

The concept of political economics is rooted in the ideas of the Marxism bureau: "Karl Mark" and "Friedrich Engels" both see class divisions as the driving force of history, with Karl Mark using a method called dialectical materialism to study his social history. However, Karl Mark sees the society in which we live, consisting of politics, culture, art, literature, and law, defined by the mode of production that is a combination of productive force. This includes production tools, labor force and social and technical relations of production, production power and production relations forming the economic structure of economy, also known as the lower structure or economic base. In relation to the force of production, the production of goods and services, using machinery and manufacturing technology, and the relations of production are the relationship of the class, between the owner of the inputs and those who do not own the inputs, or the capitalist and the labor with the upper structure that is the subject of social institutions and social ideologies (Shaun best, 2003), and the super structure is the legal system, the political system, the social motto base, the knowledge system, the culture, traditions, and beliefs of society, the relationship between the upper and lower structures, which Karl Marx emphasizes uses the economy as a determining factor in describing the upper structure as a matter of politics, law, and social consciousness.

The relationship between capitalists and workers, causing labor exchanges, to produce goods and services through the subject of income carried out under conditions in a competitive free market system, and the struggles in terms of price, cost, and profitability that cause relationships in the form of employment, by on the one hand workers taking workers for wages to be used to buy consumer goods. While capitalists own inputs in manufacturing to have capital and have factories, but require labor to help produce goods and services, to be used to sell income and business profits, such relationships are relationships that workers consent to and rarely know are oppressed or invisible to oppression, capitalists scrape away from workers for maximum profit, by reducing costs, paying low wages, giving workersmore work and not enhancing workers' productivity, to maintain superior status, these cause more class and class differences (Nattawut Singkul, 2014).

In Karl Marx influential book capital (1867), a conceptual commodity discusses an important role in Marxist analysis, the creation of human things able to produce valuable goods and goods, both functional values (use value) where the value of an individual derived from the consumption of goods, and the exchange value, which is valued in a series of exchanges, so the workers are the one who place value on the goods, the idea has led Marx to create the idea of class extortion (Shaun Best, 2003). 
International Journal of Social Science and Economic Research

ISSN: $2455-8834$

Volume:06, Issue:05 "May 2021"

In addition, in terms of value or value, Karl Marx has used it to describe the relationship of labor power, where value or value comes from labor power, where labor is a special product that can be re-produced and created more value. Therefore, labor is important in producing the value of goods depending on the number of workers put into production, so workers can increase themselves and add value, the workforce can be produced to produce a lot, on the contrary, wages are not much compared to the labor spent and the working hours increase. Therefore, workers are like goods in the exchange system, by exchanging wages to produce goods and bringing them to purchase goods in their livelihoods. Therefore, workers are at a disadvantage compared to capitalists who own capitalist inputs, while workers do not have the money or capital to use exchange labor, such exchanges take place in a highly competitive free market system, price-dependent production, reducing production costs to generate profits, causing a class-based extortion process, wage restrictions, increasing working hours, non-welfare benefits that should be made to workers, including facilities, a good working environment and job security, there is also no skill enhancement or practice of progressive expertise for workers (Nattawut Singkul, 2014).

The main characteristics of capitalism are the relationship between capitalists and workers, the unequal relationship, the class division process, the labor relationship with the production of goods, where the value of goods comes from the body of the workforce rather than the goods, and the workforce can create more value of its own. Meanwhile, capitalists hire workers to produce goods and to generate profits, while workers use bodies and intelligence in exchange for wages to buy goods and services in living. At the same time, capitalists use labor extortion methods to make gains for themselves, either in terms of hard work, low pay, or not paying wages, which leads to a sense of workers' dissolution (Nattawut Singkul, 2014). From the work itself made of goods and services produced and the environment to work, such relationships bring conflict between capitalists and the working class, by struggling of the working class, while the capitalist class is also trying to establish institutions to regulate in various ways (Bureaucratic Control), both divisions, controlled by bosses, to control the working class from moving under work in capitalism, make such conflicts bring to social isolation and the problem of social inequality.

\section{Political Economic Theory of Sports and Football}

\section{1). The concept of political economy in sports}

Knowledge of sports politics began in 1956, starting with Rottenberg (1956), that knowledge was developed from two political economics bureaus, namely:

(1) Neokomsik Economics Bureau, which is a bureau with an Anglo-Saxon tradition in 


\section{International Journal of Social Science and Economic Research}

ISSN: $2455-8834$

Volume:06, Issue:05 "May 2021"

North America. That is to say, it is an analysis that focuses primarily on microeconomics, applying supply and demand concepts to formally establish models regarding athlete behavior, in creating subjects related to that sport. The Neoclassical Economics Bureau places importance on professional sports, especially team-based sports, using quantitative research methods, such as statistical analysis in economics called Econometrics (Tawee Piyaosotsan, 2017).

(2) The office of popular institutions, where the office of popular institutions in sports analysis is a popular institutional concept, often occurs. In European countries, popular institutions are considered to be economics theorists outside the mainstream from neoclassical economics, the knowledge of this bureau concept values both professional and amateur sports, such as sports for fun, sports that have evolved into an industry, for example, the office of popular institutions often likes to study the importance of using private sponsors, and public subsidies on sports management (Tawee Piyaosotsan, 2017).

In the study of political economics on football in Thailand, institutional education is used because the knowledge of the office of popular institutions is consistent with the development of professional football and amateur football, as well as factors in both the football business that has evolved to the current level of the football industry.

\section{2). The concept of political economy in football}

The concept of political economics on sport is consistent and can be adapted to the concept of political economics on football in many dimensions, whether it is in terms of club promotion or as a matter of income, compensation for athletes, and extortion issues from football clubs, etc.

(1) The impact and causes that limit football players' promotion, Rottenberg has proposed that the ultimate for-profit goal of the sport will allow owners of football clubs to behave in a way that diversifies athletes' talents, and that athletes will always be able to move around. Therefore, it will be found that a famous team or a giant team, such as Buriram United, a Muang Thong United team, will also be the team that can win over smaller clubs, due to the pursuit of maximum profit.

(2) Football clubs aim for the highest profits or to win matches, indeed every club wants to make a profit, no club wants to lose money with investing in a football club, as Rottenberg has said that the ultimate profiteering in sporting events is the motivation and main goal of the club, but Kasenne sees Rottenberg as not only wanting maximum profit or money, but what is needed is victory and success. 


\section{International Journal of Social Science and Economic Research}

ISSN: $2455-8834$

Volume:06, Issue:05 "May 2021"

(3) The problem of athlete exploitation, economists has studied sports using the concept of labor economics as a basis for analysis. As a result, it is possible to study whether athletes as workers are exploited by club owners, based on the salaries of athletes in professional sports clubs, the analysis has been divided into 2 approaches, as follows:

(3.1) guidelines based on the neoclassical economics bureau aimed at offering in salary terms, where it should be (Normative Approach) of the supposed athletes.

(3.2) a positive approach that, in fact, the salaries of athletes are defined by what factors.

4) The impact of the reputation of professional sports clubs, as the current increasing popularity of professional sports has led to less prestigious sports games being questioned, that such sports games draw much less spectators than famous sports teams, that fewer fanswill weaken teams, and not succeed in competition (Kotler Philip, 1997).

Therefore, political economics and football in Thailand are inertly related in many ways, whether it is the legal system, the political system, the services, or capitalists and the workforce, all of which are related, for example, capitalists and workers are like football players and club owners with a relationship between capitalists and workers, creating the first power to change labor (Nattawut Singkul, 2014), to produce success and victory in the competition, whereby the capitalist is the owner of the club. It costs a training ground, and training equipment, requiring athletes to make money either by sponsoring matches, or selling sports jerseys to fans, to generate revenue and profits for the club. Perhaps athletes don't realize they're being extorted from capitalists, by low pay but high profits, provided athletes train hard but without raising wages for athletes, etc.

\section{Conclusion}

This article provides a presentation of the cognitive state of professional football club analysis in Chiang Mai, using the concept of political economics and the concept of political economics on football, with consistent concepts and links to political economics concepts, as follows:

1. The political economics concept of Marxism, which sees the process of developing capitalism, political power plays an important role in the fight to take over excess value, which is consistent with football club administrations with relationships with politicians, such as football club administrations with ties to politicians. However, if known football clubs in Thailand are all managed under politicians, as football can be 


\section{International Journal of Social Science and Economic Research}

ISSN: $2455-8834$

Volume:06, Issue:05 "May 2021"

used as a tool to build a political power base both in the economy, and to build the image of an organization or club. If any sport is to be used to build a political power base, it is not possible to overlook the most popular sports in Thailand such as football, the management and management of professional football clubs is another way to drive political power. At present it is undeniable that football games have nothing to do with politics, since almost every football club in Thailand is owned not only as a government agency, but mostly as a kinship of politicians who hold more thanhalf the rights, and it is also said that football clubs are used as political tools, and as political spaces for communicating with the public instead of in the political arena.

2. The concept of political economics scrapping the class, Marx has said that the social relationship between employers who use employees only for profit, and profits is due to the inequality of employers exploiting employees, this concept demonstrates exploitation towards inferior individuals, in which individuals without their own capital or ownership have no choice but to sell labor to capitalists. While workers do not have capital, use labor in exchange, by exchanging is in the form of wages while workers do not have the money or capital to use exchange labor, class extortion on the part of football clubs, football clubs are scrapping athletes by spending longer than reasoned practices, not allowing athletes to recuperate in due time, or whether it is a matter of athlete welfare. Some clubs may be concealed or concealed in this respect during the signing of athletes, and in most cases football players are exploited for wages, and athletes' contracts, due to the current period of coronavirus situation, athletes are cut salaries and terminated in large numbers. Some clubs have halved the salaries of athletes, which is a fairly hefty and violent act for athletes, which can sometimes be caused by the non-qualified of athletes who do not completely read the contract, but on the other hand these actions of football clubs in Thailand are frequently occurring. Therefore, the football association of Thailand has established the professional footballers' association to help football players who have been extorted and exploited bythese clubs.

3. The concept of political economics carries and develops ideas, with this political economics concept initiated and apparently this idea clearly from the 17th century, which is a period of struggle between capitalism and feudalism in Europe, capitalist economists focusedon only things and objects. Under the assumption that "human beings are economic animals that seek the best personal interests, it cannot make us understand society", and it is not undeniable that we can see all the realities in society, that humans believe that they are economic and political animals that must be involved and rely on economic and political activities at all times. For example, production, consumption and exchange, or distribution of produce in various ways, humans in this sense are considered 


\section{International Journal of Social Science and Economic Research}

ISSN: $2455-8834$

Volume:06, Issue:05 "May 2021"

to be creatures full of economic and political activity and filled with competitive competition and fighting for power in allocating resources, which, if compared in terms of football, is not the only one. Nowadays, it is undeniable that it is a business competition and a competition to gain maximum power and success, in the football business, profiting from the football business is not only receiving money from sponsors or tickets to watch sports games, matches and souvenirs, but also trading sports, trading sports players of football clubs is another business of football clubs to earn money into the club. Some clubs with thick funds will buy top players with high skills and talent from different clubs into the club, which, compared to some clubs that use cats to look in search of athletes from places that are not very famous but may have skills that many clubs may not see, train and develop until they can be said to be top athletes, and in the end these ordinary or unremarkable footy athletes. In the future, it will be possible to generate huge profits and money for the club in the future. Some clubs even have to scramble these athletes into clubs so that they are famous and popular with fans around the world to generate money and make the most of the profits for the club, each of which has a different approach, which they benefit from.

\section{Reference}

Best, S. (2005). A beginner's Guide to Social Theory. England. : The University of Winchester.

Daily Resolutions. (2019). Football and politics penetrate the fan base, love clubs, have to choose the owners. (Online) Source :web site https://www.matichon.co.th/ .

Kiedkaew, F. (1977). Physical education history. Bangkok: SCB.

Krispetch, T. (1995). Thai Physical Education. Bangkok: Chulalongkorn University.

Pidphayan, U. (1974). Development of Physical Education in Thailand. Master of Education Thesis, Department of Physical Education, Faculty of Education, Chulalongkorn University.

Philip, K. (1997). Marketing Management : Analysis, Planning, Implement, and Control. 9thed., Prentice-Hall, Inc.

Piyaosotsan, T. (2017). The political economics of conflict in the management of local professional football in the eastern case study chanthaburi FC. Master of Public Administration Thesis (Local Administration) Faculty of Political Science, Rampaipanee Rajabhat University. 
Pojjanalawan, P. (2007). Thai football politics of the game under the foot Geography, Politics and the Game of New Power in Thailand. (Online) Source: web site https://prachatai.com/journal/2012/07/41491.

Singkul, N. (2014). Political economics concept theory. (Online) Source: web sitehttp://nattawutsingh.blogspot.com/2014/01/blog-post_4774.html.

Wikipedia, the free encyclopedia, (2021). Thai Football League Company. (Online) Source: web site https://th.wikipedia.org/wiki/ League_(Company) .13 April 2021. 